\title{
EQUILIBRATION AND INCREASE OF HEMOGLOBIN CONCENTRATION AFTER ONE UNIT WHOLE BLOOD TRANSFUSION AMONG PATIENTS NOT ACTIVELY BLEEDING
}

\author{
HOQUE MM ${ }^{1}$, ADNAN SD ${ }^{2}$, KARIM $^{3}$, AL MAMUN MA ${ }^{4}$, NANDY $\mathrm{S}^{5}$, FARUKI MA ${ }^{6}$, MAHMUD K ${ }^{7}$, \\ ISLAM $\mathrm{K}^{8}$
}

\begin{abstract}
:
Background: Transfusion is a specialized modality of patient management and lifesaving intervention. The decision to transfuse should be individualized, based on a rational approach and taking into account the hemoglobin value in addition to physiologic variables. The purpose of this study was to determine the amount of increase in haemoglobin levels and the rapidity of equilibration after single unit fresh whole blood transfusion in medical inpatients not actively bleeding among the Bangladeshi population.
\end{abstract}

Methods: The present cross sectional study was conducted at the Department of Transfusion Medicine, Dhaka Medical College, Dhaka during the periods of July 2012 to June 2013. Total 100 purposively selected admitted patients in the Department of Medicine of Dhaka Medical College Hospital (DMCH) undergone blood transfusion were included in the study. Demographic characteristics were obtained from the clinical records and by face to face interview. Haemoglobin concentration was measured before transfusion, after 6 hours and 24 hours of transfusion using standard laboratory method. Data were analyzed using SPSS version 16 (SPPS Incorporation, Chicago, IL, USA). Comparison between mean values of haemoglobin was compared with student's $t$-test and two-sided $\mathrm{P}$ value of 0.05 or less was considered significant.

Results: The mean $\pm S D$ of the age of the respondents was $24.17 \pm 4.96$ years with a range of 19 to 45 years and $90.0 \%$ were male and $10.0 \%$ were female. Previous blood donation history present in $72.0 \%$ respondents and absent in $28.0 \%$ respondents. Mean $\pm S D$ of $\mathrm{Hb}$ level before, 6 hours and 24 hours after transfusion were 7.64 $1.05,8.03 \pm 1.07$ and $8.78 \pm 1.19 \mathrm{gm} / \mathrm{dl}$ respectively. In the present study the mean increase of $\mathrm{Hb} 6$ hours and 24 hours after transfusion were $0.39 \mathrm{gm} / \mathrm{dl}$ and $1.14 \mathrm{gm} / \mathrm{dl}$ respectively. Comparison between mean Hb level of before transfusion with 6 hours and 24 hours after transfusion revealed a statistically significant difference. Comparison between mean $\mathrm{Hb}$ level at 6 hours and 24 hours after transfusion also revealed a statistically significant difference.

Conclusion: The study revealed slightly more one gram increase of $\mathrm{Hb}$ at 24 hours after transfusion of one unit of whole blood among patients not actively bleeding. There is significant difference between $\mathrm{Hb}$ level at 6 hours and 24 hours after transfusion.

Key Words: Blood Transfusion; Haemoglobin; Equilibration.

J Dhaka Med Coll. 2014; 23(2) : 161-166

1 Prof. Dr. Md. Mazharul Hoque, Professor, Department of Transfusion Medicine, Dhaka Medical College, Dhaka

2 Dr. Sheikh Daud Adnan, Assistant Professor, Department of Transfusion Medicine, National Institute of Cardiovascular Diseases, Dhaka

3 Dr. Shanaz Karim, Assistant Professor, Department of Transfusion Medicine, Dhaka Medical College, Dhaka

4 Dr. Mohd Abdullah Al Mamun, Project Officer, Anti tobacco program, National Heart Foundation Hospital \& Research Institute, Mirpur, Dhaka

5 Dr. Subir Nandy, Assistant Registrar, Department of Transfusion Medicine, Dhaka Medical College Hospital, Dhaka

6 Dr. Musanna Al Faruki, Registrar, Department of Medicine, Ad-din Women's Medical College, Moghbazar, Dhaka

7. Dr. Khurshid Mahmud, Associate Professor, Department of Physical Medicine, National Institute of Neuroscience (NINS), Dhaka

8. Dr. Kashfia Islam, Student, MD (Transfusion Medicine), 3rd Part, Bangabandhu Sheikh Mujib Medical University, Shahbag, Dhaka

Correspondence : Prof. Dr. Md. Mazharul Hoque, Professor, Department of Transfusion Medicine, Dhaka Medical College, Dhaka 


\section{Introduction:}

Transfusion of blood is a lifesaving intervention and millions of units of blood are collected and transfused every year worldwide ${ }^{1-5}$. It is a specialized modality of patient management; primary purpose is to increase oxygen supply by increasing arterial content of oxygen, which is dependent on the hemoglobin level ${ }^{6-10}$. The decision to transfuse a hospitalized patient must balance the known risks of transfusion with appropriate utilization of blood as a scarce resource ${ }^{11}$. Although multiple critical steps are taken to minimize the risk of infection from transfusion of blood or blood products in developed countries, the risk of transmission of disease through transfusion, can never be entirely eliminated ${ }^{6,12}$. Thus it should be considered in terms of risk versus benefit ${ }^{6}$. Transfusions should be planned judiciously and, side by side, efforts should be made to minimize the risk of disease transmission through adopting the guidelines of World Health Organization (WHO) for safe blood transfusion ${ }^{6}$.

The decision to transfuse should be individualized, based on a rational approach and taking into account the hemoglobin value in addition to physiologic variables ${ }^{10}$. In any decision to transfuse, one must weigh the risks and benefits associated with transfusion against those associated with anemia. Although blood transfusions have been associated with adverse outcomes, anemia is also associated with increased mortality rates ${ }^{13-16}$. The costs of blood transfusion are particularly complex to assess because of the many factors that have to be taken into consideration such as blood collection and screening for pathogens; blood component processing, including leuko reduction, storage, transport to the transfusion facility; administration of blood to the patient; management of potential short- and long-term transfusion-related side effects ${ }^{10,17}$.

A common assumption among clinicians is that the transfusion of a "unit" of blood will result in a $3 \%$ increase in the hematocrit or $1 \mathrm{~g} / \mathrm{dL}$ of hemoglobin ${ }^{18-21}$. It has been implied that blood volume is expanded immediately after transfusion and does not return to normal for
24 hours $^{22}$. Wiesen et al $(1994)^{23}$ found an increase in hemoglobin concentration of $20 \pm 2$ $\mathrm{g} / \mathrm{L}(2 \pm 0.2 \mathrm{~g} / \mathrm{dL})$ after 2 "units" of blood were transfused. Equilibration of hemoglobin concentration after transfusion has been estimated to take about 24 hours, but some studies have shown that earlier measurements reflect steady-state values in persons who have not bled recently ${ }^{24}$.

The purpose of this study was to determine more precisely how much of an increase in the haemoglobin is produced by transfusion of a fresh whole blood in a clinical setting. It also conducted to describe the time required for equilibration of hemoglobin concentration after single unit fresh whole blood transfusion in medical inpatients not actively bleeding. Study will enrich our knowledge and which will help to develop specific guideline of blood transfusion among the Bangladeshi population. This study will help to assist physicians and other healthcare providers in the correct selection of patients for transfusion and related laboratory test for safe administration of blood and blood products.

\section{Methodology:}

The present cross sectional study was conducted at the Department of Transfusion Medicine, Dhaka Medical College, Dhaka during the periods of July 2012 to June 2013. The protocol approved by Ethical Committee of Bangladesh Medical Research Council (BMRC) before commencement of the study. It was assured that all information and records would be kept confidential. Total 100 purposively selected admitted patients in the department of medicine of Dhaka Medical College Hospital (DMCH) undergone blood transfusion were the study population. The aims and objectives of the study along with its procedure, risks and benefits of this study were explained to the respondent in easily understandable local language. Patients age more than 18 years, normal kidney function, normal liver function, no active bleeding, and in a stable clinical phase of their disease and ability to give a written informed consent were included in the study. A structured questionnaire and a check list used as a research instrument after duly 
pre-tested. Demographic characteristics were obtained from the clinical records and by face to face interview. Haemoglobin concentration was measured before transfusion, after 6 hours and 24 hours of transfusion using standard laboratory method. Data were analyzed using SPSS version 16 (SPPS Incorporation, Chicago, IL, USA). Continuous variables were presented as mean $\pm \mathrm{SD}$, and categorical variable were as frequency and percentage. Comparison between mean values of haemoglobin was compared with student's t-test and 95\% confidence interval was also applied. A twosided $P$ value of 0.05 or less was considered significant.

\section{Results:}

The mean $\pm \mathrm{SD}$ of the age of the respondents was $24.17 \pm 4.96$ years with a range of 19 to 45 years. Out of 100 respondents 90 were male and 10 were female. Previous blood donation history present in $72.0 \%$ respondents and absent in $28.0 \%$ respondents [Table-I]. In the present study the mean increase of $\mathrm{Hb}$ after 6 hours of transfusion and after 24 hours of transfusion were $0.39 \mathrm{gm} / \mathrm{dl}$ and $1.14 \mathrm{gm} / \mathrm{dl}$ respectively [Table-II].

Comparison between mean $\mathrm{Hb}$ level of before transfusion and 6 hours after transfusion revealed a statistically significant difference $(t$ $=-28.86, \mathrm{df}=99, \mathrm{p}<.001)$. Hb level of 6 hours after transfusion $(\mathrm{M}=8.03, \mathrm{SD}=1.07)$ reported significantly higher than $\mathrm{Hb}$ level of before transfusion $(\mathrm{M}=7.64, \mathrm{SD}=1.05)$ [Table-III].
Table-I

Distribution of characteristics of the blood donors

\begin{tabular}{lcc}
\hline Variables & Frequency & Percentage \\
\hline Age group & & \\
$<25$ & 54 & 54.0 \\
$26-30$ & 26 & 26.0 \\
$31-35$ & 11 & 11.0 \\
$>36$ & 09 & 09.0 \\
Mean \pm SD (Range) & $24.17 \pm 4.96(19-45)$ \\
Sex & & \\
Male & 90 & 90.0 \\
Female & 10 & 10.0 \\
History of previous blood donation & \\
Present & 72 & 72.0 \\
Absent & 28 & 28.0 \\
\hline
\end{tabular}

Table-II

Mean increase of haemoglobin after 6 hours and 24 hours of transfusion

\begin{tabular}{lc}
\hline Haemoglobin level & Mean increase \\
\hline After 6 hours of transfusion & $0.39 \mathrm{gm} / \mathrm{dl}$ \\
After 24 hours of transfusion & $1.14 \mathrm{gm} / \mathrm{dl}$ \\
\hline
\end{tabular}

Comparison difference between mean $\mathrm{Hb}$ level of before transfusion and 24 hours after transfusion revealed a statistically significant difference $(t=-37.05, \mathrm{df}=99, \mathrm{p}<.001)$. Hb level of 24 hours after transfusion $(\mathrm{M}=8.78, \mathrm{SD}=$ 1.19) reported significantly higher than $\mathrm{Hb}$ level of before transfusion ( $\mathrm{M}=7.64, \mathrm{SD}=1.05$ ) [TableIV]. Comparison between mean $\mathrm{Hb}$ level of 6 hours and 24 hours after transfusion also revealed a statistically significant difference $(\mathrm{t}$ $=-26.98, \mathrm{df}=99, \mathrm{p}<.001)$. Hb level of 24 hours after transfusion $(\mathrm{M}=8.78, \mathrm{SD}=1.19)$ reported significantly higher than $\mathrm{Hb}$ level of 6 hours after transfusion $(\mathrm{M}=8.03, \mathrm{SD}=1.07)$ [Table-IV] .

\section{Table-III}

Comparison of mean $\mathrm{Hb}$ level before transfusion and 6 hours after transfusion

\begin{tabular}{lcccccc}
\hline & $\begin{array}{c}\text { Before } \\
\text { transfusion }\end{array}$ & $\begin{array}{c}\text { After 6 hours of } \\
\text { transfusion }\end{array}$ & $\mathrm{t}$ & $\mathrm{df}$ & $\mathrm{P}$ & $\begin{array}{c}95 \% \\
\text { value }\end{array}$ \\
\hline Hb level $($ Mean $\pm \mathrm{SD})$ & $7.64 \pm 1.05$ & $8.03 \pm 1.07$ & -28.86 & 99 & 0.000 & $-0.41--0.36$ \\
\hline
\end{tabular}

Table-IV

Comparison of mean $\mathrm{Hb}$ level of before transfusion and 24 hours after transfusion

\begin{tabular}{lcccccc}
\hline & $\begin{array}{c}\text { Before } \\
\text { transfusion }\end{array}$ & $\begin{array}{c}\text { After 24 hours of } \\
\text { transfusion }\end{array}$ & $\mathrm{t}$ & $\mathrm{df}$ & P value & 95\% CI \\
\hline Hb level (Mean $\pm \mathrm{SD})$ & $7.64 \pm 1.05$ & $8.78 \pm 1.19$ & -37.05 & 99 & 0.000 & $-1.20--1.08$ \\
\hline
\end{tabular}


Table-V

Comparison of mean $\mathrm{Hb}$ level 6 hours and 24 hours after transfusion

\begin{tabular}{lcccccc}
\hline & $\begin{array}{c}\text { After } 6 \text { hours } \\
\text { of transfusion }\end{array}$ & $\begin{array}{c}\text { After } 24 \text { hours } \\
\text { of transfusion }\end{array}$ & $\mathrm{t}$ & $\mathrm{df}$ & $\mathrm{P}$ value & $95 \% \mathrm{CI}$ \\
\hline Hb level $($ Mean $\pm \mathrm{SD})$ & $8.03 \pm 1.07$ & $8.78 \pm 1.19$ & -26.98 & 99 & 0.000 & $-0.80--0.69$ \\
\hline
\end{tabular}

\section{Discussion:}

Major textbooks state that an increase of $10 \mathrm{~g} /$ $\mathrm{L}(1 \mathrm{~g} / \mathrm{dL})$ of hemoglobin is expected per unit of blood transfused ${ }^{20,25-28}$. After transfusion, the rate at which the hemoglobin concentration equilibrates takes about 24 hours, but the supporting evidence is scant ${ }^{25,28,29}$. The ability to rapidly determine the increase in hemoglobin levels after transfusion is important in managing outpatients and acutely ill patients. A standard time to measure the hemoglobin levels would save unnecessary blood draws.

In the present study the mean \pm SD of the age of the respondents was $24.17 \pm 4.96$ years with a range of 19 to 45 years and $90.0 \%$ were male and $10.0 \%$ were female. Previous blood donation history present in $72.0 \%$ respondents and absent in $28.0 \%$ respondents. Sareen et al. $(2012)^{30}$ in their study reported that $60.5 \%$ of donors were young, below 30 years of age and were predominantly male $(91.6 \%)$.

A common assumption among clinicians is that the transfusion of one unit of blood will result in a $3 \%$ increase in the hematocrit or $1 \mathrm{~g} / \mathrm{dL}$ of hemoglobin ${ }^{18-21}$. It has been implied that blood volume is expanded immediately after transfusion and does not return to normal for 24 hours $^{22}$. Mean \pm SD of $\mathrm{Hb}$ level before, at 6 hours and 24 hours after transfusion were $7.64 \pm 1.05,8.03 \pm 1.07$ and $8.78 \pm 1.19 \mathrm{gm} / \mathrm{dl}$ respectively. In the present study the mean increase of $\mathrm{Hb} 6$ hours and 24 hours after transfusion were $0.39 \mathrm{gm} / \mathrm{dl}$ and $1.14 \mathrm{gm} / \mathrm{dl}$ respectively. Huber et al. (1964) ${ }^{18}$ found the average increase in hemoglobin concentrations was $0.9 \pm 0.1 \mathrm{~g} / \mathrm{dL}$ ) in a study of 16 adult patients with mild splenomegaly. Wiesen et al (1994) ${ }^{23}$ in their study concluded that transfusion with 1 unit of packed erythrocytes increases the hemoglobin level an average of $10 \mathrm{~g} / \mathrm{L}(1.0 \mathrm{~g} / \mathrm{dL})$. Mungayi et al. $(2014)^{31}$ in their study reported that the mean
$( \pm \mathrm{SD})$ haemoglobin concentration before transfusion was $7.38 \mathrm{~g} / \mathrm{dl}( \pm 1.71)$ and the mean change in haemoglobin concentration following blood transfusion was $2.29 \mathrm{~g} / \mathrm{dl}( \pm 1.18)$, after transfusing an average of $1.95( \pm 0.83)$ units of packed cells. Wright et al. (2014) ${ }^{32}$ in a study reported that the mean (sd) haemoglobin $(\mathrm{Hb})$ concentration increased from $8.3(1.2)$ to 11.2 (1.4) g dl(-1) after transfusion of a median (range) of 3 (1-4) units of packed red cells. Elizalde et al. (1997) ${ }^{24}$ in their study reported that the administration of 2 units of packed red cells elicited a 24-hour increase of $22.4 \pm 6.8$ $\mathrm{g} / \mathrm{L}$ in hemoglobin concentration.

An independent samples t-test was conducted to examine whether there was a significant difference between mean $\mathrm{Hb}$ level of before transfusion and 6 hours after transfusion and the test revealed a statistically significant difference $(\mathrm{t}=-28.86, \mathrm{df}=99, \mathrm{p}<.001)$. Hb level of 6 hours after transfusion $(\mathrm{M}=8.03, \mathrm{SD}=1.07)$ reported significantly higher than $\mathrm{Hb}$ level of before transfusion $(\mathrm{M}=7.64, \mathrm{SD}=1.05)$. Comparison difference between mean $\mathrm{Hb}$ level of before transfusion and 24 hours after transfusion revealed a statistically significant difference $(t=-37.05, d f=99, p<.001)$. Hb level of 24 hours after transfusion $(\mathrm{M}=8.78, \mathrm{SD}=$ 1.19) reported significantly higher than $\mathrm{Hb}$ level of before transfusion $(\mathrm{M}=7.64, \mathrm{SD}=1.05)$. Comparison between mean $\mathrm{Hb}$ level of 6 hours and 24 hours after transfusion also revealed a statistically significant difference $(t=-26.98$, $\mathrm{df}=99, \mathrm{p}<.001) . \mathrm{Hb}$ level of 24 hours after transfusion $(\mathrm{M}=8.78, \mathrm{SD}=1.19)$ reported significantly higher than $\mathrm{Hb}$ level of 6 hours after transfusion $(\mathrm{M}=8.03, \mathrm{SD}=1.07)$. Wiesen et al (1994) ${ }^{23}$ in their study concluded that hemoglobin measurements made 15 minutes after packed erythrocytes transfusion reflect steady state values. Elizalde et al. (1997) ${ }^{24}$ in their study reported that the agreement between 15-minute and 24-hour values was 
excellent, as only 6 percent of patients exhibited a clinically significant difference $(>6 \mathrm{~g} / \mathrm{L})$ between the hemoglobin measurements. This fact would allow a rapid assessment of the effects of transfusion and of the recurrence of bleeding in patients remaining at risk.

\section{Conclusion:}

The study revealed slightly more one gram increase of $\mathrm{Hb}$ at 24 hours after transfusion of one unit of whole blood among patients not actively bleeding. There is significant difference between $\mathrm{Hb}$ level at 6 hours and 24 hours after transfusion. A single centre study involving a small number of patients and luck of a homogenous study population are the limitations of this study. Collaborative research with multiple centers or institutions may be taken which will raise the scientific expertise of our researchers and physicians.

\section{Acknowledgement:}

We gratefully acknowledge Bangladesh Medical Research Council (BMRC) for support in this research study.

\section{References:}

1. Napolitano LM, Kurek S, Luchette FA, et al. Clinical practice guideline: red blood cell transfusion in adult trauma and critical care. Crit Care Med 2009; 37(12): 3124-3157.

2. Chasse Mi, English SW, McIntyre L, Knoll G, Shehata N, Forster A, Wilson K, van Walraven C, Tinmouth A, Fergusson DA. Effect of blood donor characteristics on transfusion outcomes: a protocol for systematic review and meta-analysis. Systematic Reviews 2014; 3: 28.

3. Surgenor DM, Wallace EL, Hao HS, Chapman RH. Collection and transfusion of blood in the United States, 1982-1988. N Engl J Med 1990; 322:16461651.

4. Wallace EL, Surgenor DM, Hao HS, An J, Chapman RH, Churchill WH. Collection and transfusion of blood and blood components in the United States, 1989. Transfusion 1993; 33: 139144.

5. McCullough J. The nation's changing blood supply system. JAMA. 1993; 269:2239-2245.

6. Mahmud $Z$. Are the blood transfusions safe! JAFMC Bangladesh 2009; 5( 1):1-2.

7. Raat $\mathrm{NJ}$ and Ince C. Oxygenating the microcirculation: the perspective from blood transfusion and blood storage. Vox Sang 2007; 93:12-18.
8. Vincent JL and Piagnerelli M. Transfusion in the intensive care unit. Crit Care Med 2006;34:S96101.

9. Tinmouth A, Fergusson D, Yee IC, Hebert PC. Clinical consequences of red cell storage in the critically ill. Transfusion 2006;46:2014-2027.

10. Lelubre C and Vincent J-L. Red blood cell transfusion in the critically ill patient. Annals of Intensive Care 2011; 1: 43

11. Marshall JC. Transfusion trigger: when to transfuse? Critical Care 2004;8(Suppl 2): S31-S33.

12. MacDonald NE, O’Brien SF, Delage G. Canadian Paediatric Society, Infectious Diseases and Immunization Committee. Transfusion and risk of infection in Canada: Update 2012. Paediatr Child Health 2012; 17(10): e102-e111

13. Carson JL, Duff A, Poses RM, Berlin JA, Spence $R K$, Trout R, et al. Effect of anaemia and cardiovascular disease on surgical mortality and morbidity. Lancet 1996;348:1055-1060.

14. Mudumbai SC, Cronkite R, Hu KU, Wagner T, Hayashi K, Ozanne GM, et al. Association of admission hematocrit with 6-month and 1-year mortality in intensive care unit patients. Transfusion 2011;51:2148-2159.

15. Sakr Y, Lobo S, Knuepfer S, Esser E, Bauer M, Settmacher U, et al. Anemia and blood transfusion in a surgical intensive care unit. Crit Care 2010;14:R92.

16. Vincent J-L. Indications for Blood Transfusions: Too Complex to Base on a Single Number? Ann Intern Med 2012;157:71-72.

17. Shander A, Hofmann A, Gombotz H, Theusinger OM, Spahn DR: Estimating the cost of blood: past, present, and future directions. Best Pract Res Clin Anaesthesiol 2007; 21: 271-289.

18. Huber H, Lewis SM, Szur L. The influence of anaemia, polycythaemia and splenomegaly on the relationship between venous hematocrit and redcell volume. Br J Haematol 1964; 10: 567-575.

19. Chaplin $\mathrm{H}$ and Cassell $\mathrm{M}$. Changes in the recipient's plasma hemoglobin concentration after transfusion with stored blood. Bibl Haematol 1962;13:467-469.

20. Barnes A. Blood component therapy. In: Bick RL, editor. Hematology: clinical and laboratory practice. St. Louis, MO: Mosby--Year Book; 1993. p 1653

21. Simon TL. Red cell transfusion. In: Rossi EC, Simon TL, Moss GS, editors. Principles of transfusion medicine. Baltimore, MD: Williams \& Wilkins; 1991. p 97. 
22. Rovin BH. Renal diseases. In: Dunagan WC, Ridner ML, eds. Manual of Medical Therapeutics. 26th ed. Boston: Little, Brown; 1989:221.

23. Wiesen AR, Hospenthal DR, Byrd JC, Glass KL, Howard RS, Diehl Louis F. Equilibration of hemoglobin concentration after transfusion in medical inpatients not actively bleeding. Ann Intern Med. 1994;121(4):278-280.

24. Elizalde JI, Clemente J, Marin JL, Panes J, Aragon B, Mas A, Pique JM, Teres J. Early changes in hemoglobin and hematocrit levels after packed red cell transfusion in patients with acute anemia. Transfusion 1997;37(6):573-576.

25. Simpson MB. Transfusion therapy for hematologic diseases. In: Koepke JA, ed. Laboratory Hematology. New York: Churchill Livingstone; 1984:1149.

26. Jones J. The transfusion of red cells. In: Mollison PL, Engelfreit CP, Contreras M, eds. Blood Transfusion in Clinical Medicine. 9th ed. Oxford: Blackwell Scientific Publications; 1993:423.

27. Johnston MF. Blood component therapy. In: Rutman RC, Miller WV, eds. Transfusion Therapy,
Principles and Procedures. 2d ed. Rockville: Aspen; 1985:35.

28. Keeling RP and Alberico TA. Transfusion therapy. In: Thorup OA Jr, ed. Fundamentals of Clinical Hematology. Philadelphia: W.B. Saunders; 1987:932.

29. Widmann FK, ed. Technical Manual of the American Association of Blood Banks. 9th ed. 1985:7-8.

30. Sareen R, Gupta GN, Dutt A. Donor awareness: key to successful voluntary blood donation [v1; ref status: approved with reservations 2, http:// f1000r.es/Rxchpk] F1000Research 2012;1:29 (doi: 10.12688/f1000 research.1-29.v1).

31. Mungayi V, Sharif T, Odaba DS, Blood transfusion and oxygen extraction ratio in patients admitted to the general intensive care unit: A quasi experimental study. African Journal of Emergency Medicine 2014;4(2):66-70.

32. Wright SE, Pearce B, Snowden CP, Anderson H, Wallis JP. Cardiopulmonary exercise testing before and after blood transfusion: a prospective clinical study. Br J Anaesth 2014;113(1):91-96. 